OPEN ACCESS

Edited by:

Stuart Findlay,

Cary Institute of Ecosystem Studies,

USA

Reviewed by:

Jérôme Comte,

Laval University, Canada

Courtney Creamer,

Commonwealth Scientific

and Industrial Research Organisation,

Australia

*Correspondence:

Chao Liang

State Key Laboratory of Forest and

Soil Ecology, Institute of Applied

Ecology, Chinese Academy of

Sciences, Shenyang, 110164, China

cliang823@gmail.com

Specialty section:

This article was submitted to

Terrestrial Microbiology,

a section of the journa

Frontiers in Microbiology

Received: 01 August 2014

Accepted: 14 April 2015

Published: 05 May 2015

Citation:

Liang C, Gutknecht JLM

and Balser TC (2015) Microbial lipid

and amino sugar responses

to long-term simulated global

environmental changes in a California

annual grassland.

Front. Microbiol. 6:385

doi: 10.3389/fmicb.2015.00385

\section{Microbial lipid and amino sugar responses to long-term simulated global environmental changes in a California annual grassland}

\author{
Chao Liang ${ }^{1,2 *}$, Jessica L. M. Gutknecht ${ }^{3}$ and Teri C. Balser ${ }^{2,4}$ \\ ${ }^{1}$ State Key Laboratory of Forest and Soil Ecology, Institute of Applied Ecology, Chinese Academy of Sciences, Shenyang, \\ China, ${ }^{2}$ Department of Soil Science, University of Wisconsin-Madison, Madison, WI, USA, ${ }^{3}$ Department of Soil, Water and \\ Climate, University of Minnesota, Twin Cities, MN, USA, ${ }^{4}$ Department of Soil and Water Science, University of Florida, \\ Gainesville, FL, USA
}

Global environmental change is predicted to have major consequences for carbon cycling and the functioning of soil ecosystems. However, we have limited knowledge about its impacts on the microorganisms, which act as a "valve" between carbon sequestered in soils versus released into the atmosphere. In this study we examined microbial response to continuous 9-years manipulation of three global change factors (elevated $\mathrm{CO}_{2}$, warming, and nitrogen deposition), singly and in combination using two methods: lipid and amino sugar biomarkers at the Jasper Ridge Global Change Experiment (JRGCE). The two methods yielded important distinctions. There were limited microbial lipid differences, but many significant effects for microbial amino sugars. We found that $\mathrm{CO}_{2}$ was not a direct factor influencing soil carbon and major amino sugar pools, but had a positive impact on bacterial-derived muramic acid. Likewise, warming and nitrogen deposition appeared to enrich residues specific to bacteria despite an overall depletion in total amino sugars. The results indicate that elevated $\mathrm{CO}_{2}$, warming, and nitrogen deposition all appeared to increase bacterial-derived residues, but this accumulation effect was far offset by a corresponding decline in fungal residues. The sensitivity of microbial residue biomarker amino sugars to warming and nitrogen deposition may have implications for our predictions of global change impacts on soil stored carbon.

Keywords: lipid, amino sugar, microbial biomass, microbial residue, warming, nitrogen deposition, elevated $\mathrm{CO}_{2}$, soil carbon stabilization

\section{Introduction}

Within the context of global change, it is recognized that carbon (C) stabilization in soils is of critical importance, and a better understanding of C biogeochemistry is needed (Lal, 2004; Davidson and Janssens, 2006). Because soil C cycling is ultimately the consequence of microbial growth and activity, the mechanistic basis for understanding $\mathrm{C}$ decomposition, transformation, and stabilization in soils lies in a detailed understanding of general microbial physiology and activities, which may act as a "valve" between $\mathrm{C}$ sequestered in soils versus released into the atmosphere. It has been well established that the dynamics of the terrestrial $\mathrm{C}$ pool are heavily influenced by the catabolic 
and anabolic activities of microorganisms (Balser, 2005; Schimel and Schaeffer, 2012), and that these activities are essential for biogeochemical cycling, climate change, and ecosystem sustainability (Schimel et al., 2007; Bardgett et al., 2008; Liang and Balser, 2011). However, the direct incorporation of microbial residues (microbial cellular components from both living and senesced biomass), into stable soil C pools (specifically those whose turnover time can be on the order of centuries) has received less attention (Liang et al., 2011; Miltner et al., 2012; Lee and Schmidt, 2014).

Microorganisms can be considered responsible for both the formation and turnover of stable soil C. They decrease the stable C pool by the process of decomposition, but also can contribute to it by production and turnover of their biomass (Liang et al., 2011; Miltner et al., 2012). Historically, direct microbial contribution to soil $\mathrm{C}$ sequestration has been regarded as low, and has been considered negligible or even ignored in many instances, as active microbial biomass makes up $<5 \%$ of soil organic matter (Wardle, 1992; Dalal, 1998), and has been reported as $<4 \%$ of soil organic C (Anderson and Joergensen, 1997). However, this may be misleading as living biomass alone does not properly indicate long-term $\mathrm{C}$ dynamics (Potthoff et al., 2008). Microorganisms can utilize easily degradable substrates for biomass synthesis, and residual parts of their biomass accumulate in soils when they turn over. In the iterative process of cell generation, growth and death, microorganisms continuously add to soil stable C pool. Therefore, microbial "necromass" (senesced cell components) rather than standing biomass may be a better indicator of microbial contribution to soil C pools.

Microbial residues are now thought to play a far greater role in the sequestration of $\mathrm{C}$ into soil stable $\mathrm{C}$ pools than traditionally believed (Kindler et al., 2006, 2009; Simpson et al., 2007a; Miltner et al., 2009; Liang et al., 2011). Microbial necromass can exist as relatively recalcitrant polymers, some of which are resistant to decomposition, and have been suggested as important components of the relatively stable $\mathrm{C}$ pool in soils (Guggenberger et al., 1999; Glaser et al., 2004; Liang et al., 2008). In fact, because of their rapid growth and constant turnover, microbial residues accumulate greatly over time, and therefore the contribution of microbial-derived C in soils is potentially quite large (Liang et al., 2011). Recent analytical work also confirms this: using nuclear magnetic resonance analysis, it has been found that microbial components and metabolic products are shown to have similar structures to stable humic substances that qualitatively indicates a significant incorporation of microbial-derived C (Simpson et al., 2007a,b). Further, microbial-derived sugars are stabilized in finer soil over time, as indicated by high ratios of hexose to pentose (Guggenberger et al., 1994; Kiem and Kogel-Knabner, 2003). In sum, microbial residues can result in a net contribution of microbial-derived $\mathrm{C}$ to the soil stable $\mathrm{C}$ pool. As it is well established that the stable soil organic $\mathrm{C}$ pool is the most important for long-term C sequestration (Swift, 2001), research on formation, storage and transport of microbial residues in soils is critical for understanding microbial involvement and control over the stabilization of organic $\mathrm{C}$, and further global C cycling.
To date investigations about potential ecosystem C storage in response to climate change have not been focused on the degree to which soil microbial-derived $\mathrm{C}$ persists and changes, but rather have been focused more generally on the transformation of plantderived C. However, given the potential significance of microbial contribution to, and control over, stable soil C, accurate prediction of the impact of climate change drivers on soil organic $\mathrm{C}$ will likely require understanding the response of microbial-derived recalcitrant compounds to a range of environmental factors that affect microbial growth and activities (such as soil water, nitrogen deposition, temperature). While there are studies addressing these independently (Millar et al., 2004; van Groenigen et al., 2007; Zhang et al., 2014), few have explicitly investigated their simultaneous impact.

A detailed understanding of $\mathrm{C}$ transformation and sequestration driven by microbial communities can not be obtained by analysis of bulk microbial biomass alone, as incorporation of microbial biomass $\mathrm{C}$ into soil organic $\mathrm{C}$ does not significantly increase the total C to the soil (Potthoff et al., 2008). Also, measurement of total microbial residues is difficult since reliable differentiation between the $\mathrm{C}$ bound in microbial residues and soil extant organic $\mathrm{C}$ is still unavailable. Alternatively, biomarker molecules can be used to trace the microbial origin of soil organic C (Boschker and Middelburg, 2002; Joergensen and Emmerling, 2006). Microbial residues contain characteristic amino sugars that can be used as time-integrated biomarkers because of their absence in plants (Amelung, 2001), and their stability against degradation (Nannipieri et al., 1979; Chantigny et al., 1997). Microbial amino sugars have been shown to be a relatively stable fraction of the microbial biomass, and persist after cell death, thus the proportion of total amino sugars to total soil $\mathrm{C}$ has been used to characterize the relative contribution of the microbial community to soil C turnover and storage (Guggenberger et al., 1999; Amelung, 2001; Glaser et al., 2004; Joergensen and Emmerling, 2006; Niggemann and Schubert, 2006).

In this study, we quantify living microbial biomass using lipid analysis and microbial residues by amino sugar analysis in a California annual grassland ecosystem continuously exposed for 9 years to elevated $\mathrm{CO}_{2}$, water addition, warming, and nitrogen $(\mathrm{N})$ deposition, alone or in combination, at the Jasper Ridge Global Change Experiment (JRGCE) facility. These four factors have widely been shown to impact above ground $\mathrm{C}$ dynamics (plant production and turnover; i.e., Dukes et al., 2005), and our intent with the work reported here was to increase our corresponding understanding of their impact on below ground C, using microbial residues as a proxy. The two methods - lipid and amino sugar analysis reflect microbial components with very different turnover times. Lipids (with their rapid turnover following cell death) represent the extant, active community, and amino sugars (which have been shown to persist indefinitely in soil) are reflective of both extant and past soil communities. We propose that by using both methods it is possible to identify nuances of the long-term effects on soil $\mathrm{C}$ that would be missed by conventional bulk $\mathrm{C}$ analysis (Schmidt et al., 2015). Based on prior work indicating no significant impact of water addition on general microbial community structure (Gutknecht et al., 
2012), we chose to focus on $\mathrm{CO}_{2}$, temperature, and nitrogen. We hypothesized that above-ground elevated $\mathrm{CO}_{2}$ treatment,would have little direct impact on microbial community structure or residues and that temperature and nitrogen treatments would have an effect on microbial residues after 9 years [though the exact direction of change was unclear; both elevated temperature and nitrogen have been shown to increase or decrease microbial stable C (Wixon and Balser, 2009; Wang et al., 2014a,b; Griepentrog et al., 2015)]. More specifically our objectives were to: (1) examine and quantify soil microbial response to 9 years of continuous global environmental changes using methods reflecting two distinct timescales of microbial biomass production and turnover; and (2) explore the mechanism and potential feedbacks of microbial-derived C contribution to soil C storage under global environmental changes.

\section{Results}

\section{Microbial Lipids}

We did not find any statistically significant differences $(P>0.05)$ in fungal, bacterial, or total microbial lipid biomass (nmol/g-soil) among all treatments (Figure 1A). General linear model (GLM) analysis showed an insignificant impact of elevated $\mathrm{CO}_{2}$, warming and $\mathrm{N}$ deposition on general lipid indices (Table 1). With regard to more specific microbial group abundance among simulated global change treatments, the $\mathrm{N}$ addition treatment had lower levels of arbuscular mycorrhizal fungi (AMF) and higher saprotrophic fungi (SF) compared with other global change treatments, resulting in a significantly $(P<0.05)$ lower AMF/SF ratio for $\mathrm{N}$ deposition alone (Figure 1B). Gram-positive $\left(\mathrm{Gm}^{+}\right)$bacteria and actinomycetes tended to show similar patterns among global change treatments as those of SF (Figure 1C), with an increase under $\mathrm{N}$ deposition and decrease with other factors. In treatments with more than one factor, the abundance of the microbial groups (AMF, SF, $\mathrm{Gm}^{+}$, and actinomycete) fell between the values of those in single-factor treatments (Figure 1).

\section{Microbial Amino Sugars}

We found that total amino sugars and the amounts of GluN, GalN, and ManN ( $\mu \mathrm{g} / \mathrm{g}$-soil) were depleted, while the bacterialderived MurA was enriched, under all the JRGCE global change treatments (Figure 2). The GLM analysis showed that temperature and $\mathrm{N}$ impacted the overall size of the amino sugar pool as well as the proportions of the total amino sugars in the total $\mathrm{C}$ pool; $\mathrm{CO}_{2}$ had little effect on total amino sugars but did significantly affect the individual amino sugar MurA (Table 1). More specifically, temperature and $\mathrm{N}$ were both associated with a significant decrease in the total amino sugar abundance by 52.8 and $23.8 \%$ respectively (Figure $2 \mathbf{A}$ ), and a significant enrichment in MurA by 18.7 and $37.8 \%$ respectively (Figure 2E). Elevated $\mathrm{CO}_{2}$, on the other hand, showed a suppressive effect in the amount of MurA when in combination with elevated temperature or $\mathrm{N}$ addition (Figure 2E). The ratios of GluN/GalN and GluN/MurA, a way to measure the amino sugar pattern shift, showed distinct trends. We found that elevated temperature was significantly related to lower GluN/GalN and GluN/MurA ratios, while elevated $\mathrm{CO}_{2}$ had no effect. Nitrogen deposition tended to be related to an increased GluN/GalN ratio but a decreased GluN/MurA ratio (Figure 3).

\section{Microbial-Derived C Contribution}

For our second objective, we used the proportion of amino sugars to total soil $\mathrm{C}$ as an indication of the relative contribution of microbial-derived residues to stored soil C. Total soil C significantly $(P<0.01)$ increased under $\mathrm{N}$ deposition. We found that the amino sugar proportion of total $\mathrm{C}$ was not significantly affected by elevated $\mathrm{CO}_{2}$, but was negatively affected by warming and $\mathrm{N}$ deposition. Also, the negative effects of warming and $\mathrm{N}$ deposition were not significantly altered by the addition of $\mathrm{CO}_{2}$ as a factor (there was no interactive effect of $\mathrm{CO}_{2}$ with these treatments; Figure 4). An interactive effect of warming with elevated $\mathrm{N}$ and $\mathrm{CO}_{2}$ does, however, appear to have a suppressive effect compared with $\mathrm{N}$ deposition alone or $\mathrm{N}$ deposition coupled with elevated $\mathrm{CO}_{2}$ (Figure 4).

\section{Discussion}

Our objectives were to investigate response to 9 years of continuous environmental manipulation using two methods of microbial biomarker analysis and to examine contribution of microbialderived $\mathrm{C}$ to soil stable $\mathrm{C}$ pools. Changes in microbial lipids reflect an immediate/rapid response to a changed environment, and amino sugars reflect cumulative long-term change. We used lipids and amino sugars simultaneously to study the responses of microorganisms under simulated global environmental changes, and to evaluate the role of microbial ecology in soil $\mathrm{C}$ dynamics. Through these simultaneous measurements, we also assess and compare potential long-term sensitivity of soil $\mathrm{C}$ to global change.

\section{Responses to Global Change Treatments Microbial Biomass (Lipids)}

We found that total living microbial biomass (lipid abundance) did not differ significantly under any treatment. Changes in microbial biomass under global change scenarios could be important, since microbial biomass has been known as an early indicator of changes in total soil organic C (Powlson et al., 1987). Past studies have shown inconsistent trends for microbial biomass under elevated $\mathrm{CO}_{2}$, warming, or $\mathrm{N}$ deposition. Reported responses vary in direction and magnitude, and much uncertainty exists on whether microbial biomass will increase, decrease or remain the same under elevated $\mathrm{CO}_{2}$ (Zak et al., 2000), warming (Zhang et al., 2005; Frey et al., 2008; Bell et al., 2010) or $\mathrm{N}$ deposition (Treseder, 2008). In addition to various mechanisms that contribute to observed microbial abundance, the inconsistency among studies could be a result of high variations in the analysis of microbial living biomass, or in quickly changing dynamics of the living microbial biomass. However, despite the lack of biomass response in this study, microbial community structure did differ in some ways after 9 years of continuous treatment. In particular, fungal community composition appeared altered (AMF to SF ratio). This is aligned with results from Rillig et al. (2002) and Treseder (2004), who found 


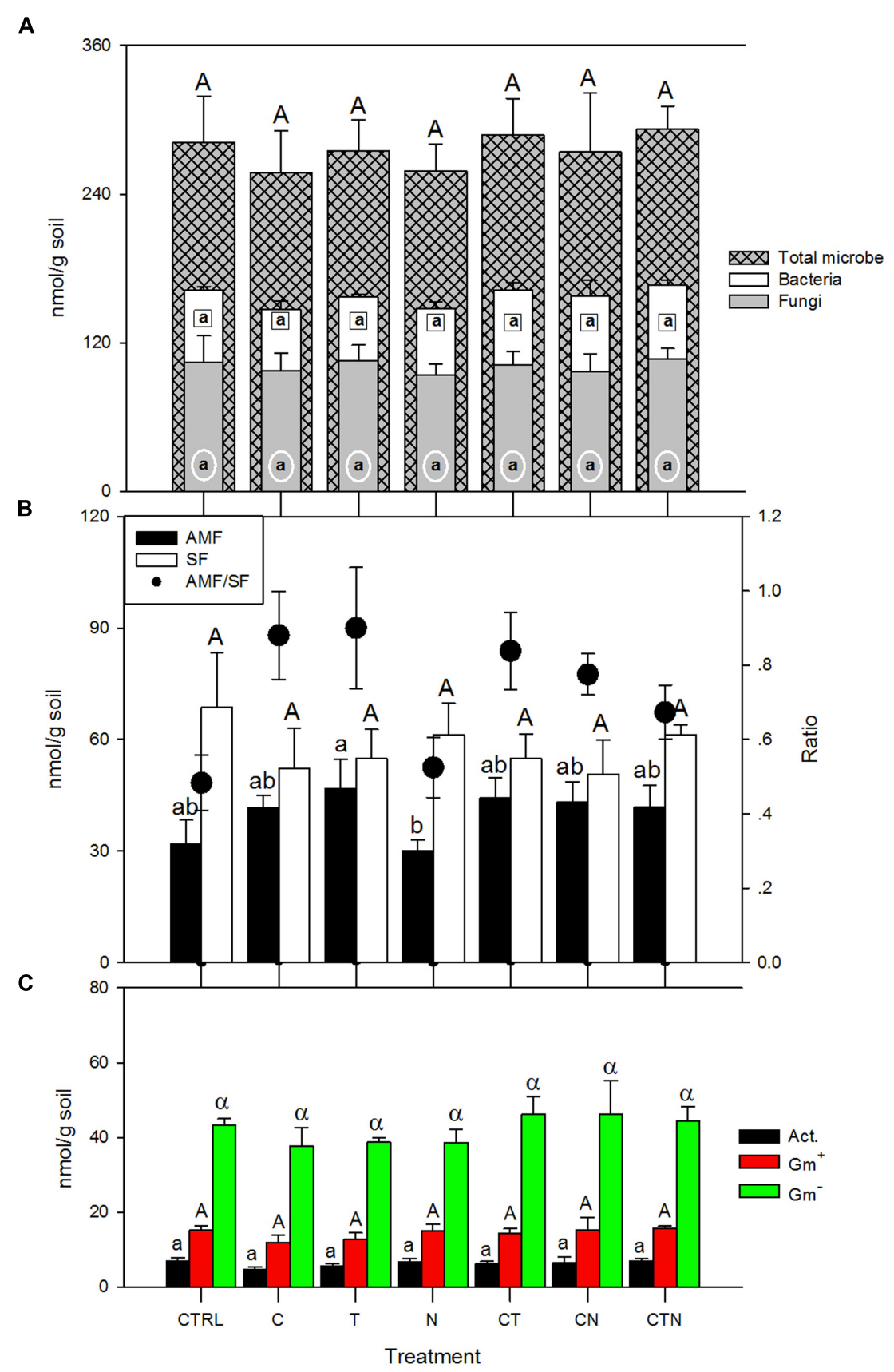

FIGURE 1 | Lipid guild abundance ( $\mathrm{nmol} / \mathrm{g}$ soil) under single and combined global change treatments. Bars indicate SE of the mean $(n=4$ or 5). Bars sharing the same letter are not significantly different $(P=0.05, \mathrm{LSD}$ test). CTRL, control; C, elevated $\mathrm{CO}_{2}$; T, elevated temperature; $\mathrm{N}$, nitrogen deposition; AMF, arbuscular mycorrhizal fungi; SF, saprotrophic fungi; $\mathrm{Gm}^{+}$, gram-positive bacteria; $\mathrm{Gm}^{-}$, gram-negative bacteria; Act., actinomycete. that AMF abundance increased under elevated $\mathrm{CO}_{2}$ and soil warming. In contrast, AMF abundance here did not significantly change under $\mathrm{N}$ fertilization compared with the control (Figure 1B). Two mechanisms have been proposed regarding the $\mathrm{N}$ addition influence on AMF: (1) increased $\mathrm{N}$ has a negative effect on AMF abundance as AMF become C-limited when $\mathrm{N}$ is more available and plants correspondingly reduce allocation of C to mycorrhizal association (Treseder, 2004; van Diepen et al.,
2007); (2) AMF proliferation following $\mathrm{N}$ addition has also been reported in some ecosystems, possibly because of extreme $\mathrm{N}$ limitation and an increased plant recruitment of AMF (Anderson and Liberta, 1992; Treseder and Allen, 2002). Here, we did not find a significant difference in AMF abundance compared with the control, possibly indicating that multiple mechanisms were involved, or that after 9 years the fungal communities have acclimated to the new level of $\mathrm{N}$-availability. 
TABLE 1 | Summary of F-ratios from a general linear model, testing for the integrative effects of treatments on amino sugars, lipids, total carbon and nitrogen after 9-years global change manipulation.

\begin{tabular}{|c|c|c|c|c|c|c|}
\hline \multirow[b]{2}{*}{ Variable } & \multicolumn{6}{|c|}{ Treatment } \\
\hline & C & $\mathbf{T}$ & $\mathbf{N}$ & C.T & $\mathbf{C} \cdot \mathbf{N}$ & C.T.N \\
\hline TC\% & 0.10 & 0.00 & $19.60^{* * * *}$ & $3.14^{*}$ & 1.05 & 2.20 \\
\hline TN\% & 0.10 & 0.00 & $15.78^{* * * *}$ & $2.99 *$ & 0.87 & 0.53 \\
\hline Total lipids (nmol/g) & 0.17 & 0.73 & 0.08 & 0.01 & 0.02 & 0.04 \\
\hline Fungal lipids (nmol/g) & 0.01 & 0.88 & 0.03 & 0.07 & 0.00 & 0.04 \\
\hline AMF lipids (nmol/g) & 1.44 & 2.62 & 0.01 & 2.68 & 0.00 & 0.15 \\
\hline SF lipids (nmol/g) & 1.44 & 2.62 & 0.01 & 2.68 & 0.00 & 0.15 \\
\hline Bacterial lipids (nmol/g) & 0.86 & 0.18 & 0.47 & 0.25 & 0.17 & 0.89 \\
\hline SF to AMF ratio & 5.06 & 0.48 & 0.65 & $4.09^{\star}$ & 0.07 & 0.51 \\
\hline $\mathrm{Gm}^{+}$to $\mathrm{Gm}^{-}$ratio & 2.78 & 0.18 & 0.46 & 1.79 & 0.23 & 0.53 \\
\hline Total AS (ug/g) & 0.26 & $37.36^{* * * *}$ & 1.61 & 0.78 & 2.27 & $5.39^{* *}$ \\
\hline GluN (ug/g) & 0.63 & $40.11^{* * * *}$ & 0.73 & 0.64 & 2.63 & $5.21^{* *}$ \\
\hline GalN (ug/g) & 0.13 & $21.67^{* * * *}$ & $4.66^{* *}$ & 0.55 & 1.31 & $5.30^{* *}$ \\
\hline MurA (ug/g) & $16.59^{* * * *}$ & 0.92 & $14.2^{* * *}$ & 0.16 & $18.11^{* * * *}$ & 0.43 \\
\hline $\mathrm{AS} / \mathrm{TC}(\mathrm{mg} / \mathrm{g})$ & 0.22 & $32.82^{* * * * *}$ & $12.05^{* * *}$ & $4.05^{*}$ & $4.68^{* *}$ & $6.57^{* *}$ \\
\hline GluN/TC (mg/g) & 0.47 & $35.58^{* * * *}$ & $9.40^{* * *}$ & $3.69^{*}$ & $4.99^{* *}$ & $6.59^{* *}$ \\
\hline GalN/TC (mg/g) & 0.11 & $21.10^{* * *}$ & $14.81^{* * *}$ & $3.04^{\star}$ & $3.05^{\star}$ & $5.77^{* *}$ \\
\hline MurA/TC (mg/g) & $8.32^{* * *}$ & 0.39 & 0.74 & 0.17 & $6.53^{* *}$ & 1.46 \\
\hline GluN/GalN ratio & 0.77 & $14.41^{* * * *}$ & $14.85^{* * * *}$ & 0.01 & 1.46 & 0.28 \\
\hline GluN/MurA ratio & $5.78^{* *}$ & $28.2^{* * * *}$ & $3.76^{*}$ & 0.66 & $13.01^{* * *}$ & $3.00^{*}$ \\
\hline
\end{tabular}

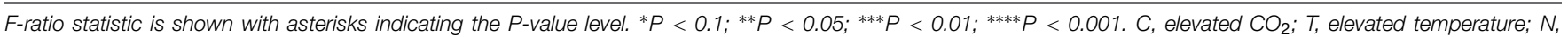

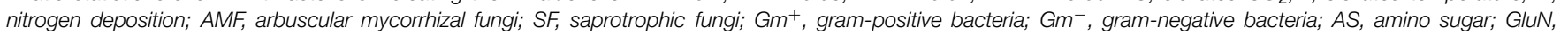
glucosamine; GalN, galactosamine; MurA, muramic acid.

\section{Microbial Residues (Amino Sugars)}

We found that total amino sugars, GluN, GalN, and ManN were significantly depleted in warming and $\mathrm{N}$ deposition treatments after 9 years, but the MurA was in greater abundance overall. This indicates that 9 years of warming and elevated $\mathrm{N}$ significantly reduced the amount of total microbial residues and fungal residues, but augmented bacterial residues. In spite of the differing effects by warming and $\mathrm{N}$ deposition on fungal and bacterial residues, they both consistently indicate that $\mathrm{N}$ addition has a generally positive effect, and warming has a generally negative effect on microbial residue accumulation. Although the complexity of soil processes makes straightforward interpretations of microbial residue dynamics difficult, we believe that the treatment-induced changes both directly and indirectly influence microbial growth, death and residue decay. The $\mathrm{N}$ additioninduced enhancement of plant growth at the JRGCE (Zavaleta et al., 2003; Dukes et al., 2005) could increase C inputs to the soil as litter and root exudation, which may directly benefit microbial growth (Treseder and Allen, 2002). However, plants may also compete with microbes for limited nutrients, which may hamper microbial growth due to nutrient limitation (Treseder, 2004). The treated plots (not $\mathrm{N}$ amended plots) at Jasper Ridge are likely a nutrient-limited environment (Menge and Field, 2007; Gutknecht et al., 2010), and plant competition likely limits microbial growth, biomass production, and accumulation. In the case of the warming treatment, changes in microbial physiology may explain the decline in the fraction of assimilated $\mathrm{C}$ that is allocated to microbial growth (Allison et al., 2010). In addition, the dominant amino sugars might be decomposed as a type of $\mathrm{N}$ nutrient for plant and microbial growth under warming and extreme nutrient-limited conditions. The distinct increase in MurA under treatments could be explained by faster bacterial life cycles associated with faster turnover rate, or a bacterial community shift from $\mathrm{Gm}^{-}$to $\mathrm{Gm}^{+}$bacteria which contain thick murein layers (Eudy et al., 1985; Kogel-Knabner, 2002).

Not surprisingly, there was no significant relationship between elevated $\mathrm{CO}_{2}$ and total amino sugars and GluN suggesting that elevated $\mathrm{CO}_{2}$ does not influence total microbial residues and fungal residues in soil (Table 1, Figures 2A,B). In addition, we only found a slight additive influence of elevated $\mathrm{CO}_{2}$ coupled with other global change factors (Figures $\mathbf{2 A}, \mathbf{B}$ ), which is in accord with the previous work on lipid dynamics over time (Gutknecht et al., 2012). In contrast, elevated $\mathrm{CO}_{2}$ was related to moderately higher bacterial-derived MurA compared to the control, suggesting that elevated $\mathrm{CO}_{2}$ may contribute to an increased concentration of bacterial-derived residues. In line with this finding, Drigo et al. (2007) found that bacterial community structure in the rhizosphere was most affected by elevated $\mathrm{CO}_{2}$, whereas fungal community structure was less influenced.

Direct effects of elevated $\mathrm{CO}_{2}$ on soil microbial communities could be expected to be negligible since the $\mathrm{CO}_{2}$ concentration in the soil pore space is much higher than the atmospheric level above the soil. However, elevated $\mathrm{CO}_{2}$ can indirectly affect soil microbial communities via plant metabolism and root secretion (Drigo et al., 2008), decreased evapotranspiration (Ainsworth and Long, 2005). The Jasper Ridge site, as with typical grassland systems, has a high volume of rhizosphere soil, which was dominated by $\mathrm{Gm}^{-}$bacteria (Figure 1C). The increase in 


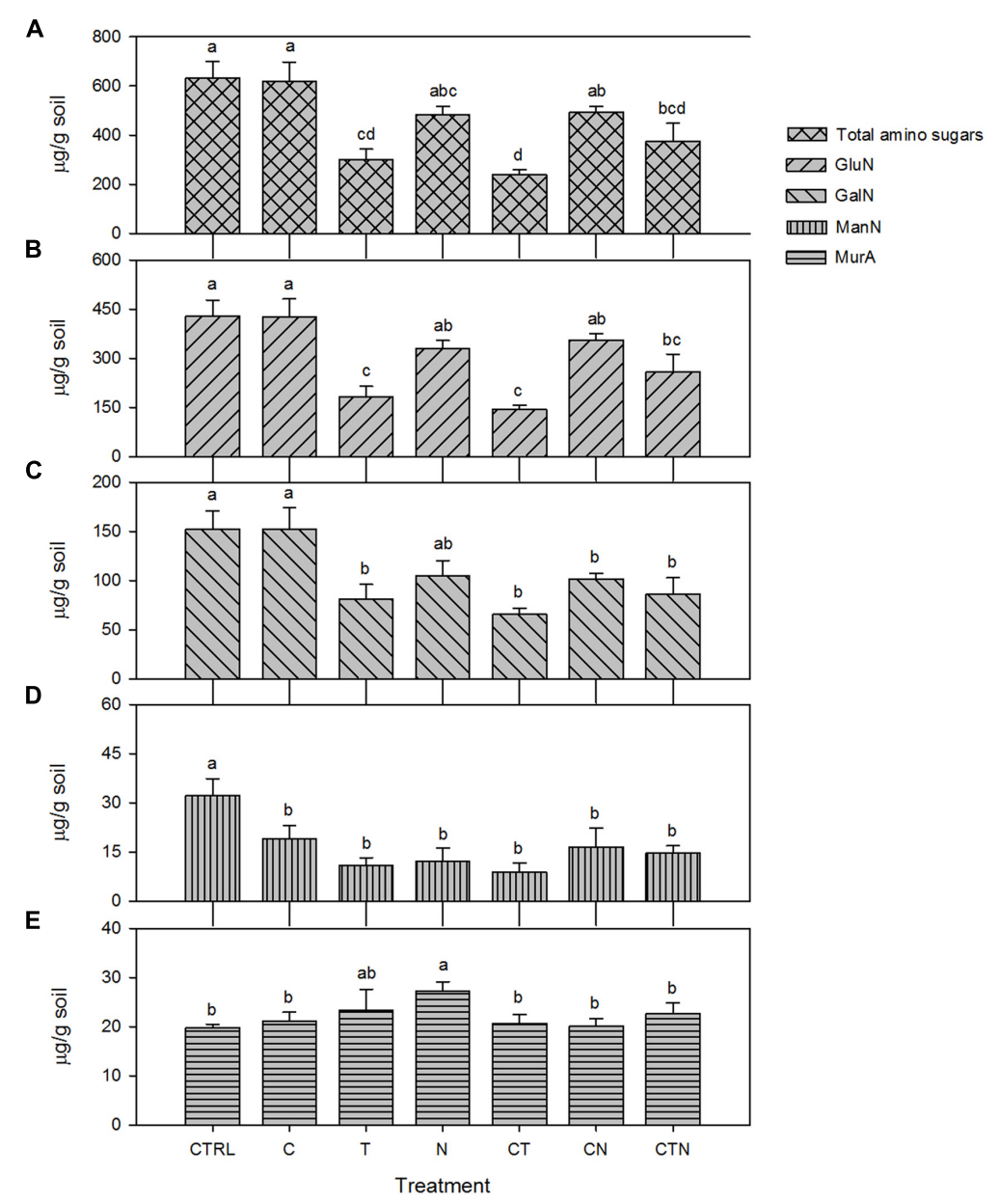

FIGURE 2 | Absolute abundance in bulk and individual amino sugars ( $\mu \mathrm{g} / \mathrm{g}$ soil) under single and combined global change treatments. Bars indicate SE of the mean ( $n=4$ or 5$)$. Bars sharing the same letter are not significantly different ( $P=0.05$, LSD test). CTRL, control; C, elevated $\mathrm{CO}_{2} ; \mathrm{T}$, elevated temperature; N, nitrogen deposition; GluN, glucosamine; GalN, galactosamine; ManN, mannosamine; MurA, muramic acid.
MurA under elevated $\mathrm{CO}_{2}$ may thus be a result of indirect plant "fertilization," increased levels of labile $\mathrm{C}$ and nutrient excreted into the rhizosphere leading to higher $\mathrm{Gm}^{-}$bacterial growth and turnover.

Variation in amino sugar ratios can be used as a qualitative indicator of time-integrated compositional changes in the soil microbial community (Guggenberger et al., 1999; Glaser et al., 2004). We found that the abundance of GalN was different from MurA among treatments, and thus ratios of GluN/GalN and GluN/MurA showed different tendencies, especially under $\mathrm{N}$ deposition where MurA was significantly increased. We suggest using the GluN/GalN ratio to describe overall amino sugar accumulation patterns (long-term microbial turnover), and the GluN/MurA ratio to understand the relative long-term contribution to soil $\mathrm{C}$ by fungi versus bacteria.

\section{Evaluation of Rapid versus Long-Term Responses of Soil Microbes}

Another interest of ours was to compare the use of the two microbial methods, each indicating something distinct about soil C. Precise prediction of microbial response to global changes has proven difficult within a specific ecosystem due to the large uncertainty regarding microbial community (Treseder et al., 2012). This could be due both to method limitations and limitations due to the timing and frequency of sampling. A single sampling of microbial biomass may not reveal microbial response to prolonged global changes, as rapid and ephemeral changes in the living microbial community may confound the perceived treatment effects. Another limitation is that the standing biomass of microbes does not necessarily reflect microbial contribution to soil $\mathrm{C}$ storage, since microbial-derived residues in nascent humic substances could have increased even while standing living biomass remains constant or decreases (Potthoff et al., 2008). It is reasonable to expect that the different microbial community responses to simulated global changes in our study should sustain microbial residue accumulations to a different degree, and the effects could be further amplified over time; while that measures of standing biomass, for instance lipids, may not reveal these long-term changes in microbial 


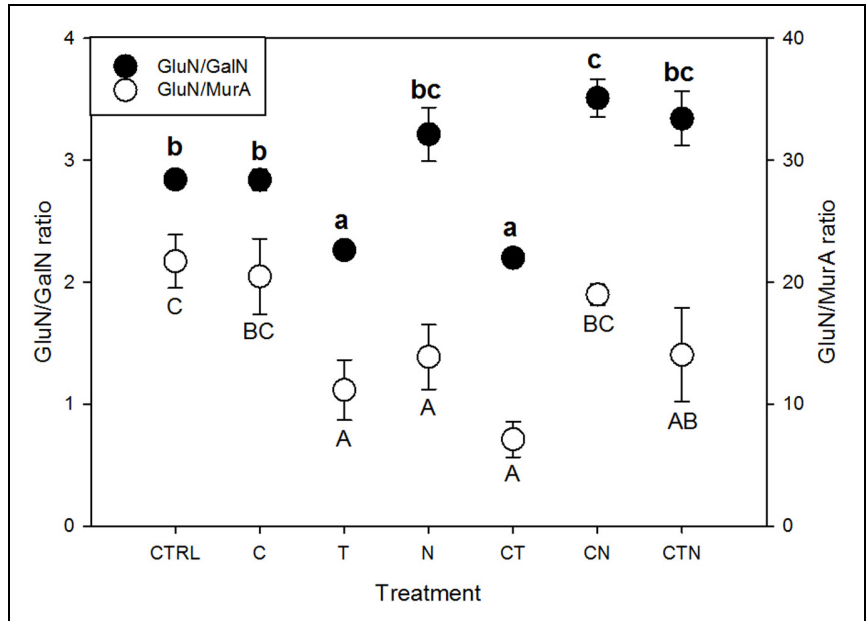

FIGURE 3 | Amino sugar ratios under single and combined global change treatments. CTRL, control; $\mathrm{C}$, elevated $\mathrm{CO}_{2} ; \mathrm{T}$, elevated temperature; N, nitrogen deposition; GluN, glucosamine; GalN, galactosamine; MurA, muramic acid. Bars indicate SE of the mean $(n=4$ or 5). Dots sharing a letter are not significantly different ( $P=0.05$, LSD test).

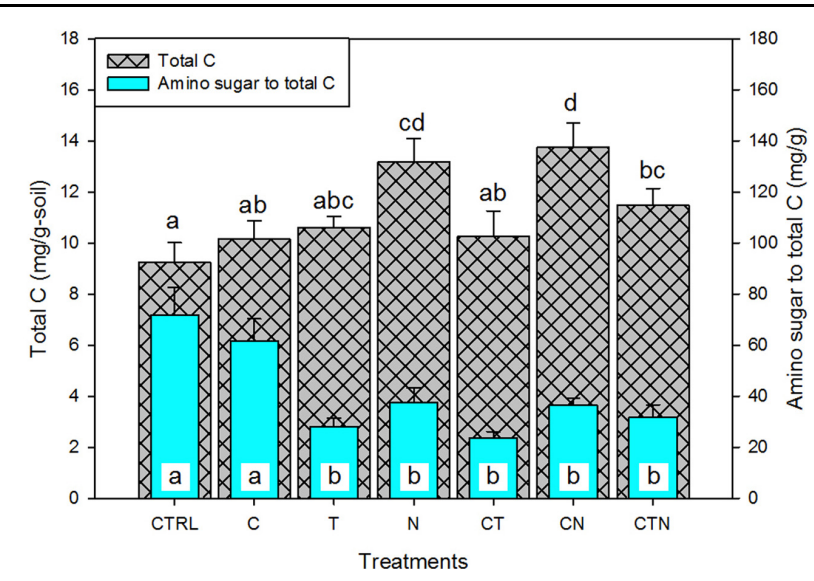

FIGURE 4 | The effect of single and combined global environmental change treatments on the total carbon pool and the proportion of bulk amino sugars in that pool. CTRL, control; C, elevated $\mathrm{CO}_{2} ; \mathrm{T}$, elevated temperature; N, nitrogen deposition. Bars indicate SE of the mean ( $n=4$ or 5). Bars sharing a letter are not significantly different ( $P=0.05$, LSD test).

contributions to soil C (Table 2). As microbial cell walls appear more stable and turn over more slowly than living microbial biomass (Guggenberger et al., 1999; Amelung, 2001; Glaser et al., 2004), microbial cell wall amino sugars provide a more useful indicator of chronic, long-term soil microbial responses and microbial necromass contributions to changes in soil $\mathrm{C}$ storage.

\section{Microbial Residue Amino Sugar Contribution to Soil C Storage}

Our second goal with this research was ultimately to go beyond describing microbial responses following 9 years of manipulation and assess the potential significance of a given response for below ground $\mathrm{C}$ storage. Toward that end, the amino sugar proportion of total soil $\mathrm{C}$ may be used to indicate microbial residue accumulation, or microbial-derived $\mathrm{C}$ contribution to soil C sequestration over time (Liang and Balser, 2012). In addition to examining absolute amino sugar amounts (indicating extant and past microbial biomass and coarse community structure), it is interesting to consider how the proportion of amino sugars to soil total $\mathrm{C}$ was altered by the global change manipulations. In the Jasper Ridge grassland ecosystem, elevated $\mathrm{CO}_{2}$ had no significant effect on total soil $\mathrm{C}$ or its proportional amino sugar content. However, under increased nitrogen and warming, total soil C showed two responses: 9-years of $\mathrm{N}$ deposition significantly increased soil total $\mathrm{C}$ storage, while warming did not statistically alter the total soil $\mathrm{C}$ pool (Figure 4). In contrast, the amino sugar proportion of total soil $\mathrm{C}$ was lowered under both warming and $\mathrm{N}$ deposition (Table 1; Figure 4). Thus microbial residues appeared to decline in contribution to total soil $\mathrm{C}$ under warming and $\mathrm{N}$ deposition compared with other C-containing compounds. This has potential implication for long-term $\mathrm{C}$ stabilization or sequestration under warming or $\mathrm{N}$ deposition. The decline in contribution of microbial $\mathrm{C}$ may reflect differing underlying impacts of the two environmental changes on microbial dynamics (Liang and Balser, 2012). Temperature is a global modulator affecting respiration, enzyme activity, and membrane fluidity all living organisms must respond in some way to a change in temperature. Increased temperature has been shown to correlate to a decline in microbial biomass (Gutknecht et al., 2012), and this decline may be responsible for the lowered contribution of amino sugars- $\mathrm{C}$ to total soil $\mathrm{C}$. Nitrogen is a resource, not a modulator. Organisms compete for it, and it is often related to increased overall biomass. Thus the lower microbial amino sugars- $\mathrm{C}$ relative to total soil $\mathrm{C}$ in this case is likely due to an increase in newer plant $\mathrm{C}$ when $\mathrm{N}$ constraints on plant production are alleviated rather than a decline in microbial contribution.

This highlights the need to look at soil $\mathrm{C}$ as more than a bulk measure, as is also being recognized in other research efforts

TABLE 2 | Summarized dynamics of lipids and amino sugars under 9-years simulated global changes in JRGCE.

\begin{tabular}{|c|c|c|c|c|c|c|c|}
\hline & \multicolumn{3}{|c|}{ Lipid } & \multicolumn{4}{|c|}{ Amino sugar } \\
\hline & Total lipids & $\begin{array}{l}\text { Fungal } \\
\text { lipids }\end{array}$ & $\begin{array}{l}\text { Bacterial } \\
\text { lipids }\end{array}$ & $\begin{array}{l}\text { Total amino } \\
\text { sugars }\end{array}$ & Glucosamine & Muramic acid & $\begin{array}{l}\text { Proportions of amino } \\
\text { sugars in soil C }\end{array}$ \\
\hline Elevated $\mathrm{CO}_{2}$ & No change & No change & No change & No change & No change & Increase & No change \\
\hline Warming & No change & No change & No change & Decrease & Decrease & Increase & Decrease \\
\hline $\mathrm{N}$ deposition & No change & No change & No change & Decrease & Decrease & Increase & Decrease \\
\hline
\end{tabular}


(Poirier et al., 2005; Schmidt et al., 2015). Assuming soil C is a single homogeneous pool ignores the fact that separate fractions have different origins or turnover time (Trumbore, 1997, 2000). The soil stable $\mathrm{C}$ pool is critical in the role of soil as a $\mathrm{C}$ sink within the global $\mathrm{C}$ cycle, as even a small change in the stable $\mathrm{C}$ pool could have large consequences for climate change (Rustad et al., 2000). In this study, microbial residue biomarker analysis allowed us to separate organic $\mathrm{C}$ of microbial origin from other fractions. While their percentage of total $\mathrm{C}$ is relatively small, microbial amino sugars may act as a canary in the mineshaft for soil C - indicating possible vulnerabilities or changes in long term stability. The sensitivity of microbial residues to warming and $\mathrm{N}$ deposition observed in this study may prove important in our predictions of global change impacts on soil stored C.

\section{Conclusion}

The overall purpose of this study was to explore soil microbial communities and potential responses of stable soil C to longterm simulated global environmental changes. We used microbial biomarkers, lipids and amino sugars, to investigate microbial responses and contribution of microbial residues. Amino sugars, as compared to lipids, provide a more useful indicator of long-term soil microbial responses, and reflect microbial residue contributions to soil C storage under chronic simulated global environmental changes. We found that an environmental modulator (temperature) and a nutrient resource (nitrogen) differed in their impact on microbial residue accumulation. Warming and $\mathrm{N}$ deposition both resulted in significantly depleted total microbial residues, and enriched bacterial residues (though offset by the corresponding decline in fungal residues).

This study highlights the power of the amino sugar analysis by directly comparing potential microbial responses on short and long time scales (using lipid and amino sugar biomarkers as reflective of these timescales, respectively) in a grassland after continuous 9-years manipulation of global multifaceted factors. We suggest that single time point microbial lipid measurements may not reveal the long-term microbial contribution to soil C in the same way that analysis of microbial amino sugars can. The study also highlights the sensitivity of microbial residues in the soil $\mathrm{C}$ stock in the context of warming and $\mathrm{N}$ deposition. We suggest the dynamics of microbial residues should be incorporated into current soil $\mathrm{C}$ research and that integration may substantially improve our predictions of global change impacts on soil stored C.

\section{Materials and Methods}

\section{Site Description}

The JRGCE contains manipulations of each of the following global change factors: (1) atmospheric $\mathrm{CO}_{2}$ concentration (ambient and $700 \mathrm{ppm}$ ), (2) temperature (ambient and +1 degree Celsius at the soil surface), (3) $\mathrm{N}$ deposition (ambient and $7 \mathrm{~g}$ $\mathrm{N} \mathrm{m}^{-2} \mathrm{y}^{-1}$ ), 4) water addition (ambient and augmented to twice ambient), with all factors crossed in a complete full factorial design (Shaw et al., 2002; Zavaleta et al., 2003). In this study we did not include samples from the water addition plots. The JRGCE was started in 1998 to test future global change scenarios for this region (Hayhoe et al., 2004). The site is located in the eastern foothills of the Santa Cruz Mountains at the Jasper Ridge Biological Preserve in the San Francisco Bay area. The region experiences a Mediterranean climate, and is generally dominated by annual non-native grasses Avena barbata and Avena fatua (Zavaleta et al., 2003). The soil at the JRGCE is a loam texture with a $\mathrm{pH}$ ranging from 6.5 to $7.0, \sim 3 \%$ organic matter and a cation exchange capacity of $9.5 \mathrm{meq} 100 \mathrm{~g} \mathrm{soil}^{-1}$. Soils were sampled on 16-17 April, 2007 from the JRGCE, corresponding with annual peak plant biomass, 9 years following the start of the experiment. Four soil cores ( $4 \mathrm{~cm}$ diameter by $15 \mathrm{~cm}$ depth) were taken from each experimental plot, 10-g sub-samples from the homogenized cores were frozen immediately, shipped to the University of Wisconsin - Madison, and freeze dried for microbial analysis. Other sub-samples were air dried for total $\mathrm{C}$ and $\mathrm{N}$ analysis. Total soil $\mathrm{C}$ and $\mathrm{N}$ data were determined by combustion analysis and provided by the JRGCE facility support staff.

\section{Microbial Analysis}

We assayed the soils for microbial amino sugars and lipids. We determined four amino sugars [glucosamine, galactosamine (GalN), mannosamine (ManN), and muramic acid] by gas chromatograph (GC) after their conversion to aldonitrile acetates according to the protocol of Guerrant and Moss (1984) and Zhang and Amelung (1996), as modified by Liang et al. (2012). Briefly, $\sim 1 \mathrm{~g}$ soil samples were hydrolyzed with $6 \mathrm{M} \mathrm{HCl}$ at $105^{\circ} \mathrm{C}$ for $8 \mathrm{~h}$, and then the solution was filtered and purified by neutralization. After drying the supernatant, methanol was used to wash amino sugars from the residues, transferred to $3 \mathrm{~mL}$ vials, and then evaporated to dryness on a Labconco 79000 RapidVap (Labconco Co., Kansas City, MO, USA). The residues were re-dissolved in $1 \mathrm{~mL}$ distilled deionized water, lyophilized overnight, and then processed for aldononitrile acetate derivatization. To prepare the aldononitrile derivatives, the amino sugars were dissolved in a derivatization reagent consisting of hydroxylamine hydrochloride (32 $\mathrm{mg} \mathrm{mL}^{-1}$ ) and 4-(dimethylamino) pyridine $\left(40 \mathrm{mg} \mathrm{mL}^{-1}\right)$ in $4: 1$ pyridine-methanol $(\mathrm{v} / \mathrm{v})$, and heated to $75-80^{\circ} \mathrm{C}$ for $35 \mathrm{~min}$. Then, $1 \mathrm{~mL}$ acetic anhydride was added, and the solution was reheated for $25 \mathrm{~min}$ for acetylation. After cooling, $1.5 \mathrm{~mL}$ dichloromethane and $1 \mathrm{~mL} 1 \mathrm{M}$ $\mathrm{HCl}$ were successively added and the mixture was vortexed to transfer the amino sugar to organic phase. The solution was washed thrice with $1 \mathrm{~mL}$ deionized $\mathrm{H}_{2} \mathrm{O}$ to remove excess anhydride. In the last washing step, the aqueous phase was removed as completely as possible. Finally, the organic phase was dried at $45^{\circ} \mathrm{C}$ in a Labconco 79000 RapidVap, and re-suspended in $300 \mu \mathrm{L}$ ethyl acetate-hexane (1:1) for GC analysis. Separation of amino sugar derivatives was carried out on an Agilent 6890 GC (Agilent Technologies, Wilmington, DE, USA) equipped with a J\&W Scientific Ultra-2 column ( $25 \mathrm{~m}$ by $0.2 \mathrm{~mm}$ by $0.33 \mu \mathrm{m})$ and flame ionization detector (FID). Sample extracts $(2 \mu \mathrm{L})$ were injected onto the column using $\mathrm{H}_{2}$ as the carrier gas at a constant flow rate of $0.4 \mathrm{~mL} \mathrm{~min}{ }^{-1}$. The GC inlet was set to $250^{\circ} \mathrm{C}$ and operated in split mode with a 30:1 ratio. The individual 
amino sugar derivatives were identified by comparing their retention time with those of authentic standards. Quantification was gained relative to the internal standard myo-inositol, which was added to the samples prior to purification, and the recovery standard $N$-methylglucamine was added before derivatization. The recovery standard was used to assess the reliability of derivatization step. Glucosamine (GluN, made by fungi and bacteria) and muramic acid (MurA, made by bacteria) are both particularly useful biomarkers. Fungal GluN is often the most abundant amino sugar found in soils, while MurA is uniquely derived from bacterial peptidoglycan (Amelung, 2001; Joergensen and Emmerling, 2006). The others, GalN and mannosamine, are less useful due to questions about their origins (Coelho et al., 1997; Amelung, 2001; Engelking et al., 2007).

We used a hybrid procedure of phospholipid fatty acid (PLFA) and fatty acid methyl ester (FAME) analysis to assay microbial community structure (Kao-Kniffin and Balser, 2007). We extracted lipids from $\sim 3 \mathrm{~g}$ freeze-dried sub-samples using a phosphate buffer, chloroform and methanol (0.9:1:2) extraction solution. Samples were extracted twice, and then the supernatant were combined together. After phase separation overnight, the organic phase isolated and evaporated to dryness using a RapidVap (LabConco, Kansas City, MO, USA). We carried out FAME analysis as described by Microbial ID Inc on the dried organic residue. Lipids were saponified, and then subjected to alkaline methanolysis. Lipids were isolated from the samples in a hexane extraction. We analyzed extracts using a Hewlett-Packard Agilent 6890 GC (Agilent Technologies, Wilmington, DE, USA) equipped with an Agilent Ultra-2 (5\% phenyl)-methylpolysiloxane capillary column ( $25 \mathrm{~m}$ by $0.2 \mathrm{~mm}$ by $0.33 \mu \mathrm{m}$ ) and FID. Lipid peaks were identified by MIDI peak identification software ("Sherlock microbial identification system,” MIDI Inc., Newark, DE, USA). Two internal standards, 9:0 nonanoic methyl ester and 19:0 nonadecanoic methyl ester, were used as internal standards to convert fatty acid peak areas to the absolute abundance at $\mathrm{nmol} / \mathrm{g}$-soil. We quantified the abundance of different microbial groups in each treatment using the abundance of lipids

\section{References}

Ainsworth, E. A., and Long, S. P. (2005). What have we learned from 15 years of free-air $\mathrm{CO}_{2}$ enrichment (FACE)? A meta-analytic review of the responses of photosynthesis, canopy properties and plant production to rising $\mathrm{CO}_{2}$. New Phytol. 165, 351-372. doi: 10.1111/j.1469-8137.2004.01224.x

Allison, S. D., Wallenstein, M. D., and Bradford, M. A. (2010). Soil-carbon response to warming dependent on microbial physiology. Nat. Geosci. 3, 336-340. doi: $10.1038 /$ ngeo846

Amelung, W. (2001). "Methods using amino sugars as markers for microbial residues in soil," in Assessment Methods for Soil Carbon, eds R. Lal, J. M. Kimble, R. F. Follett, and B. A. Stewart (Boca Raton, FL: CRC/Lewis Publishers), 233-270.

Anderson, R. C., and Liberta, A. E. (1992). Influence of supplemental inorganic nutrients on growth, survivorship, and mycorrhizal relationships of Schizachyrium scoparium (Poaceae) grown in fumigated and unfumigated soil. Am. J. Bot. 79, 406-414. doi: 10.2307/2445152

Anderson, T.-H., and Joergensen, R. G. (1997). Relationship between SIR and FE estimates of microbial biomass $\mathrm{C}$ in deciduous forest soils at different pH. Soil Biol. Biochem. 29, 1033-1042. doi: 10.1016/S0038-0717(97) 00011-4 in chemically similar 'guilds'. Microbial biomass was represented by the sum of all identifiable fatty acids (detectable at $>0.05 \%$ and $C$ number $<20$ ). Fungal, bacterial and actinomycetal biomass were represented by summing all representative PLFAs for each group. In specific, we used the sum of 14:0iso, 15:0anteiso, 15:0iso, 16:0iso, 17:0anteiso, and 17:0iso to indicate $\mathrm{Gm}^{+}$bacteria, and the sum of $16: 1 \omega 7 \mathrm{c}, 16: 1 \omega 9 \mathrm{c}, 17: 0 \mathrm{cyclo}$, $17: 1 \omega 8 \mathrm{c}, 19: 0 \mathrm{cyclo}$ and $18: 1 \omega 7 \mathrm{c}$ to indicate $\mathrm{Gm}^{-}$bacteria. The sum of 10Me18:0; 10Me17:0; 10Me16:0 represents actinomycete. AMF is indicated by $16: 1 \omega 5 \mathrm{c}$ and SF by the sum of $18: 1 \omega 9 \mathrm{c}$ and $18: 2 \omega 6 c$.

\section{Statistics}

In order to test the global change effects, we took single and combined treatments as the different levels of global change, and inferred the effects with one-way ANOVA for the abundance of individual and total lipids and amino sugars, ratios of lipids and amino sugars, and soil total C. A post hoc separation of means by LSD was performed in the cases where main effects were significant at $p<0.05$. We used a GLM to test the integrative effects of elevated $\mathrm{CO}_{2}$, warming, $\mathrm{N}$ deposition and their interactions on microbial lipids and amino sugars. Statistical analyses were performed with the SPSS (SYSTAT Software, Inc.) software for Windows, and figure preparations were accomplished using Sigma Plot (SYSTAT Software, Inc.).

\section{Acknowledgments}

The authors would like to thank Dr. Harry Read and the collaborators at the Jasper Ridge Global Change Experiment, especially Dr. Chris Field, Dr. Nona Chiariello, Todd Tobeck, and Yuka Estrada. We would also like to thank the US NSF DEB 045-2652 and the China CAS XDB15010303 funds for the support. Finally, we are grateful for the efforts of our editor and three reviewers. The manuscript is much improved as a result of their suggestions.

Balser, T. C. (2005). "Humification," in Encyclopedia of Soils in the Environment, Vol. 2, ed. D. Hillel (Oxford: Elsevier), 195-207.

Bardgett, R. D., Freeman, C., and Ostle, N. J. (2008). Microbial contributions to climate change through carbon cycle feedbacks. ISME J. 2, 805-814. doi: 10.1038/ismej.2008.58

Bell, T. H., Klironomos, J. N., and Henry, H. A. L. (2010). Seasonal responses of extracellular enzyme activity and microbial biomass to warming and nitrogen addition. Soil Sci. Soc. Am. J. 74, 820-828. doi: 10.2136/sssaj2009. 0036

Boschker, H. T. S., and Middelburg, J. J. (2002). Stable isotopes and biomarkers in microbial ecology. FEMS Microbiol. Ecol. 40, 85-95. doi: 10.1111/j.15746941.2002.tb00940.x

Chantigny, M. H., Angers, D. A., Prevost, D., Vezina, L.-P., and Chalifour, F.P. (1997). Soil aggregation and fungal and cacterial biomass under annual and perennial cropping systems. Soil Sci. Soc. Am. J. 61, 262-267. doi: 10.2136/sssaj1997.03615995006100010037x

Coelho, R. R. R., Sacramento, D. R., and Linhares, L. F. (1997). Amino sugars in fungal melanins and soil humic acids. Eur. J. Soil Sci. 48, 425-429. doi: 10.1111/j.1365-2389.1997.tb00208.x

Dalal, R. C. (1998). Soil microbial biomass: what do the numbers really mean? Aust. J. Exp. Agric. 38, 649-665. doi: 10.1071/EA97142 
Davidson, E. A., and Janssens, I. A. (2006). Temperature sensitivity of soil carbon decomposition and feedbacks to climate change. Nature 440, 165-173. doi: 10.1038/nature04514

Drigo, B., Kowalchuk, G., and van Veen, J. (2008). Climate change goes underground: effects of elevated atmospheric $\mathrm{CO}_{2}$ on microbial community structure and activities in the rhizosphere. Biol. Fertil. Soils 44, 667-679. doi: 10.1007/s00374-008-0277-3

Drigo, B., Kowalchuk, G. A., Yergeau, E., Bezemer, T. M., Boschker, H. T. S., and van Veen, J. A. (2007). Impact of elevated carbon dioxide on the rhizosphere communities of Carex arenaria and Festuca rubra. Glob. Chang. Biol. 13, 2396-2410. doi: 10.1111/j.1365-2486.2007.01445.x

Dukes, J. S., Chiariello, N. R., Cleland, E. E., Moore, L. A., Shaw, M. R., Thayer, S., et al. (2005). Responses of grassland production to single and multiple global environmental changes. PLoS Biol. 3:e319. doi: 10.1371/journal.pbio.0030319

Engelking, B., Flessa, H., and Joergensen, R. G. (2007). Shifts in amino sugar and ergosterol contents after addition of sucrose and cellulose to soil. Soil Biol. Biochem. 39, 2111-2118. doi: 10.1016/j.soilbio.2007.03.020

Eudy, L. W., Walla, M. D., Morgan, S. L., and Fox, A. (1985). Gas chromatographicmass spectrometric determination of muramic acid content and pyrolysis profiles for a group of gram-positive and gram-negative bacteria. Analyst 110, 381-385. doi: 10.1039/an9851000381

Frey, S. D., Drijber, R., Smith, H., and Melillo, J. (2008). Microbial biomass, functional capacity, and community structure after 12 years of soil warming. Soil Biol. Biochem. 40, 2904-2907. doi: 10.1016/j.soilbio.2008.07.020

Glaser, B., Turrion, M. B., and Alef, K. (2004). Amino sugars and muramic acid biomarkers for soil microbial community structure analysis. Soil Biol. Biochem. 36, 399-407. doi: 10.1016/j.soilbio.2003.10.013

Griepentrog, M., Eglinton, T. I., Hagedorn, F., Schmidt, M. W. I., and Wiesenberg, G. L. B. (2015). Interactive effects of elevated $\mathrm{CO}_{2}$ and nitrogen deposition on fatty acid molecular and isotope composition of above- and belowground tree biomass and forest soil fractions. Glob. Chang. Biol. 21, 473-486. doi: $10.1111 /$ gcb. 12666

Guerrant, G. O., and Moss, C. W. (1984). Determination of monosaccharides as aldononitrile, O-methyloxime, alditol, and cyclitol acetate derivatives by gas-chromatography. Anal. Chem. 56, 633-638. doi: 10.1021/ac00268a010

Guggenberger, G., Christensen, B. T., and Zech, W. (1994). Land-use effects on the composition of organic matter in particle-size separates of soil: I. Lignin and carbohydrate signature. Eur. J. Soil Sci. 45, 449-458. doi: 10.1111/j.13652389.1994.tb00530.x

Guggenberger, G., Frey, S. D., Six, J., Paustian, K., and Elliott, E. T. (1999). Bacterial and fungal cell-wall residues in conventional and no-tillage agroecosystems. Soil Sci. Soc. Am. J. 63, 1188-1198. doi: 10.2136/sssaj1999.6351188x

Gutknecht, J. L. M., Field, C. B., and Balser, T. C. (2012). Microbial communities and their responses to simulated global change fluctuate greatly over multiple years. Glob. Chang. Biol. 18, 2256-2269. doi: 10.1111/j.1365-2486.2012. 02686.x

Gutknecht, J. L. M., Henry, H. A. L., and Balser, T. C. (2010). Inter-annual variation in soil extra-cellular enzyme activity in response to simulated global change and fire disturbance. Pedobiologia 53, 283-293. doi: 10.1016/j.pedobi.2010.02.001

Hayhoe, K., Cayan, D., Field, C. B., Frumhoff, P. C., Maurer, E. P., Miller, N. L., et al. (2004). Emissions pathways, climate change, and impacts on California. Proc. Natl. Acad. Sci. U.S.A. 101, 12422-12427. doi: 10.1073/pnas.0404500101

Joergensen, R. G., and Emmerling, C. (2006). Methods for evaluating human impact on soil microorganisms based on their activity, biomass, and diversity in agricultural soils. J. Plant Nutr. Soil Sci. 169, 295-309. doi: 10.1002/jpln.200521941

Kao-Kniffin, J., and Balser, T. C. (2007). Elevated $\mathrm{CO}_{2}$ differentially alters belowground plant and soil microbial community structure in reed canary grass-invaded experimental wetlands. Soil Biol. Biochem. 39, 517-525. doi: 10.1016/j.soilbio.2006.08.024

Kiem, R., and Kogel-Knabner, I. (2003). Contribution of lignin and polysaccharides to the refractory carbon pool in C-depleted arable soils. Soil Biol. Biochem. 35, 101-118. doi: 10.1016/S0038-0717(02)00242-0

Kindler, R., Miltner, A., Richnow, H.-H., and Kastner, M. (2006). Fate of gramnegative bacterial biomass in soil-mineralization and contribution to SOM. Soil Biol. Biochem. 38, 2860-2870. doi: 10.1016/j.soilbio.2006.04.047

Kindler, R., Miltner, A., Thullner, M., Richnow, H.-H., and Kastner, H. (2009). Fate of bacterial biomass derived fatty acids in soil and their contribution to soil organic matter. Org. Geochem. 40, 29-37. doi: 10.1016/j.orggeochem.2008.09.005

Kogel-Knabner, I. (2002). The macromolecular organic composition of plant and microbial residues as inputs to soil organic matter. Soil Biol. Biochem. 34, 139-162. doi: 10.1016/S0038-0717(01)00158-4

Lal, R. (2004). Soil carbon sequestration impacts on global climate change and food security. Science 304, 1623-1627. doi: 10.1126/science.1097396

Lee, Z. M., and Schmidt, T. M. (2014). Bacterial growth efficiency varies in soils under different land management practices. Soil Biol. Biochem. 69, 282-290. doi: 10.1016/j.soilbio.2013.11.012

Liang, C., and Balser, T. C. (2011). Microbial production of recalcitrant organic matter in global soils: implications for productivity and climate policy. Nat. Rev. Microbiol. 9, 75. doi: 10.1038/nrmicro2386-c1

Liang, C., and Balser, T. C. (2012). Warming and nitrogen deposition lessen microbial residue contribution to soil carbon pool. Nat. Commun. 3, 1222. doi: $10.1038 /$ ncomms 2224

Liang, C., Cheng, G., Wixon, D., and Balser, T. (2011). An absorbing markov chain approach to understanding the microbial role in soil carbon stabilization. Biogeochemistry 106, 303-309. doi: 10.1007/s10533-010-9525-3

Liang, C., Fujinuma, R., and Balser, T. C. (2008). Comparing PLFA and amino sugars for microbial analysis in an Upper Michigan old growth forest. Soil Biol. Biochem. 40, 2063-2065. doi: 10.1016/j.soilbio.2008.01.022

Liang, C., Read, H. W., and Balser, T. C. (2012). GC-based detection of aldonitrile acetate derivatized glucosamine and muramic acid for microbial residue determination in soil samples: analytical protocol and derivative validation. J. Vis. Exp. 63:e3767. doi: 10.3791/3767

Menge, D. N. L., and Field, C. B. (2007). Simulated global changes alter phosphorus demand in annual grassland. Glob. Chang. Biol. 13, 2582-2591. doi: 10.1111/j.1365-2486.2007.01456.x

Millar, N., Blum, H., Lobe, I., and Glaser, B. (2004). The effect of long-term elevated atmospheric $\mathrm{CO}_{2}$ on soil amino sugars in ryegrass swards. Grassl. Sci. Eur. 9, $160-162$.

Miltner, A., Bombach, P., Schmidt-Brücken, B., and Kästner, M. (2012). SOM genesis: microbial biomass as a significant source. Biogeochemistry 111, 41-55. doi: 10.1007/s10533-011-9658-z

Miltner, A., Kindler, R., Knicker, H., Richnow, H.-H., and Kastner, H. (2009). Fate of microbial biomass-derived amino acids in soil and their contribution to soil organic matter. Org. Geochem. 40, 978-985. doi: 10.1016/j.orggeochem.2009.06.008

Nannipieri, P., Pedrazzini, F., Arcara, P. G., and Piovanelli, C. (1979). Changes in amino-acids, enzyme-activities, and biomasses during soil microbial-growth. Soil Sci. 127, 26-34. doi: 10.1097/00010694-197901000-00004

Niggemann, J., and Schubert, C. J. (2006). Sources and fate of amino sugars in coastal Peruvian sediments. Geochim. Cosmochim. Acta 70, 2229-2237. doi: 10.1016/j.gca.2006.02.004

Poirier, N., Sohi, S. P., Gaunt, J. L., Mahieu, N., Randall, E. W., Powlson, D. S., et al. (2005). The chemical composition of measurable soil organic matter pools. Org. Geochem. 36, 1174-1189. doi: 10.1016/j.orggeochem.2005.03.005

Potthoff, M., Dyckmans, J., Flessa, H., Beese, F., and Joergensen, R. (2008). Decomposition of maize residues after manipulation of colonization and its contribution to the soil microbial biomass. Biol. Fertil. Soils 44, 891-895. doi: 10.1007/s00374-007-0266-y

Powlson, D. S., Brooks, P. C., and Christensen, B. T. (1987). Measurement of soil microbial biomass provides an early indication of changes in total soil organic matter due to straw incorporation. Soil Biol. Biochem. 19, 159-164. doi: 10.1016/0038-0717(87)90076-9

Rillig, M. C., Wright, S. F., Shaw, M. R., and Field, C. B. (2002). Artificial climate warming positively affects arbuscular mycorrhizae but decreases soil aggregate water stability in an annual grassland. Oikos 97, 52-58. doi: 10.1034/j.16000706.2002.970105.x

Rustad, L. E., Huntington, T. G., and Boone, R. D. (2000). Controls on soil respiration: implications for climate change. Biogeochemistry 48, 1-6. doi: 10.1023/A:1006255431298

Schimel, J., Balser, T. C., and Wallenstein, M. (2007). Microbial stress-response physiology and its implications for ecosystem function. Ecology 88, 1386-1394. doi: 10.1890/06-0219

Schimel, J., and Schaeffer, S. M. (2012). Microbial control over carbon cycling in soil. Front. Microbiol. 3:348. doi: 10.3389/fmicb.2012.00348 
Schmidt, J., Schulz, E., Michalzik, B., Buscot, F., and Gutknecht, J. L. M. (2015). Carbon input and crop-related changes in microbial biomarker levels strongly affect the turnover and composition of soil organic carbon. Soil Biol. Biochem. 85, 39-50. doi: 10.1016/j.soilbio.2015.02.024

Shaw, M. R., Zavaleta, E. S., Chiariello, N. R., Cleland, E. E., Mooney, H. A., and Field, C. B. (2002). Grassland responses to global environmental changes suppressed by elevated $\mathrm{CO}_{2}$. Science 298, 1987-1990. doi: 10.1126/science.1075312

Simpson, A., J, Simpson, M. J., Smith, E., and Kelleher, B. P. (2007a). Microbially derived inputs to soil organic matter: are current estimates too low? Environ. Sci. Technol. 41, 8070-8076. doi: 10.1021/es071217x

Simpson, A. J., Song, G., Smith, E., Lam, B., Novotny, E. H., and Hayes, M. H. B. (2007b). Unraveling the structural components of soil humin by use of solutionstate nuclear magnetic resonance spectroscopy. Environ. Sci. Technol. 41, 876-883. doi: 10.1021/es061576c

Swift, R. G. (2001). Sequestration of carbon by soil. Soil Sci. 166, 858-871. doi: 10.1097/00010694-200111000-00010

Treseder, K. K. (2004). A meta-analysis of mycorrhizal responses to nitrogen, phosphorus, and atmospheric $\mathrm{CO}_{2}$ in field studies. New Phytol. 164, 347-355. doi: $10.1111 /$ j.1469-8137.2004.01159.x

Treseder, K. K. (2008). Nitrogen additions and microbial biomass: a metaanalysis of ecosystem studies. Ecol. Lett. 11, 1111-1120. doi: 10.1111/j.14610248.2008.01230.x

Treseder, K. K., and Allen, M. F. (2002). Direct nitrogen and phosphorus limitation of arbuscular mycorrhizal fungi: a model and field test. New Phytol. 155, 507-515. doi: 10.1046/j.1469-8137.2002.00470.x

Treseder, K., Balser, T., Bradford, M., Brodie, E., Dubinsky, E., Eviner, V., et al. (2012). Integrating microbial ecology into ecosystem models: challenges and priorities. Biogeochemistry 109, 7-18. doi: 10.1007/s10533-011-9636-5

Trumbore, S. (2000). Age of soil organic matter and soil respiration: radiocarbon constraints on belowground carbon dynamics. Ecol. Appl. 10, 399-411. doi: 10.1890/1051-0761(2000)010[0399:AOSOMA]2.0.CO;2

Trumbore, S. E. (1997). Potential responses of soil organic carbon to global environmental change. Proc. Natl. Acad. Sci. U.S.A. 94, 8284-8291. doi: 10.1073/pnas.94.16.8284

van Diepen, L. T. A., Lilleskov, E. A., Pregitzer, K. S., and Miller, R. M. (2007). Decline of arbuscular mycorrhizal fungi in northern hardwood forests exposed to chronic nitrogen additions. New Phytol. 176, 175-183. doi: 10.1111/j.14698137.2007.02150.x

van Groenigen, K.-J., Six, J., Harris, D., and Van Kessel, C. (2007). Elevated $\mathrm{CO}_{2}$ does not favor a fungal decomposition pathway. Soil Biol. Biochem. 39, 2168-2172. doi: 10.1016/j.soilbio.2007.03.009
Wang, Q., Wang, S., He, T., Liu, L., and Wu, J. (2014a). Response of organic carbon mineralization and microbial community to leaf litter and nutrient additions in subtropical forest soils. Soil Biol. Biochem. 71, 13-20. doi: 10.1016/j.soilbio.2014.01.004

Wang, Q., Wang, Y., Wang, S., He, T., and Liu, L. (2014b). Fresh carbon and nitrogen inputs alter organic carbon mineralization and microbial community in forest deep soil layers. Soil Biol. Biochem. 72, 145-151. doi: 10.1016/j.soilbio.2014.01.020

Wardle, D. A. (1992). A comparative assessment of factors which influence microbial biomass carbon and nitrogen levels in soil. Biol. Rev. 67, 321-358. doi: 10.1111/j.1469-185X.1992.tb00728.x

Wixon, D. L., and Balser, T. C. (2009). Complexity, climate change and soil carbon: a systems approach to microbial temperature response. Syst. Res. Behav. Sci. 26, 601-620. doi: 10.1002/sres.995

Zak, D. R., Pregitzer, K. S., King, J. S., and Holmes, W. E. (2000). Elevated atmospheric $\mathrm{CO}_{2}$, fine roots and the response of soil microorganisms: a review and hypothesis. New Phytol. 147, 201-222. doi: 10.1046/j.1469-8137.2000.00687.x

Zavaleta, E. S., Shaw, M. R., Chiariello, N. R., Thomas, B. D., Cleland, E. E., Field, C. B., et al. (2003). Grassland responses to three years of elevated temperature, $\mathrm{CO}_{2}$, precipitation, and $\mathrm{N}$ deposition. Ecol. Monogr. 73, 585-604. doi: 10.1890/02-4053

Zhang, W., He, H., Li, Q., Lu, C., Zhang, X., and Zhu, J. (2014). Soil microbial residue dynamics after 3-year elevated O3 exposure are plant species-specific. Plant Soil 376, 139-149. doi: 10.1007/s11104-013-1973-9

Zhang, W., Parker, K. M., Luo, Y., Wan, S., Wallace, L. L., and Hu, S. (2005). Soil microbial responses to experimental warming and clipping in a tallgrass prairie. Glob. Chang. Biol. 11, 266-277. doi: 10.1111/j.1365-2486.2005. 00902.x

Zhang, X., and Amelung, W. (1996). Gas chromatographic determination of muramic acid, glucosamine, mannosamine, and galactosamine in soils. Soil Biol. Biochem. 28, 1201-1206. doi: 10.1016/0038-0717(96)00117-4

Conflict of Interest Statement: The authors declare that the research was conducted in the absence of any commercial or financial relationships that could be construed as a potential conflict of interest.

Copyright (c) 2015 Liang, Gutknecht and Balser. This is an open-access article distributed under the terms of the Creative Commons Attribution License (CC BY). The use, distribution or reproduction in other forums is permitted, provided the original author(s) or licensor are credited and that the original publication in this journal is cited, in accordance with accepted academic practice. No use, distribution or reproduction is permitted which does not comply with these terms. 